\title{
Characterization of Probiotics Isolated from Intestine of Mackerel Fish (Rastrelliger sp.) from Lembata Regency of East Nusa Tenggara
}

\author{
Helena Daten ${ }^{1 *}$, Tri Ardyati $^{1,2}$, Yoga Dwi Jatmiko ${ }^{1,2}$ \\ ${ }^{1}$ Master Program of Biology, Faculty of Mathematics and Natural Sciences, Universitas Brawijaya, Malang \\ ${ }^{2}$ Department of Biology, Faculty of Mathematics and Natural Sciences, Universitas Brawijaya, Malang
}

\begin{abstract}
The research aimed to isolate, characterize, and analyze the ability of lactic acid bacteria (LAB) potential as probiotics to produce hydrolase enzyme. The LAB was isolated using MRS agar by the spread plate method. The LAB characterization includes antimicrobial activity, tolerance to low $\mathrm{pH}$, bile salt, salinity, autoaggregation properties, and ability to produce hydrolytic enzymes. The isolate which has the highest ability to inhibit Aeromonas hydrophila is KBP 3.3, while the isolate which inhibits the highest Streptococcus agalactiae is KBP 1.1.1. The KBP 3.3 and KBP 1.1.1 were able to survive at $\mathrm{pH} 1$ for 24 hours with a survival rate of $93.6 \%$ and $98.3 \%$. The KBP 3.3 and KBP 1.1 .1 are tolerant to $7.5 \%$ bile salt concentrations for 24 hours of $99.46 \%$ and $99.11 \%$. The KBP 3.3 is tolerant to $0.5 \%$ salinity for 24 hours with the highest survival rate of $113.38 \%$, while KBP 1.1 .1 is $94 \%$. The KBP 3.3 and 1.1 .1 have autoaggregation properties of $92.18 \%$ and 87.84\%. The KBP 3.3 produced the highest lipase enzyme, while KBP 1.1.1 produced the protease enzyme.
\end{abstract}

Keywords: hydrolytic enzyme, lactic acid bacteria, mackerel, probiotic

\section{INTRODUCTION}

Lembata Regency is located in East Nusa Tenggara Province; one of the largest producers of marine fish in Indonesia. Fish with high economic value and widely caught in Lembata Regency are mackerel (Rastrelliger sp.). Mackerel is a type of fish that live in shallow sea waters and low salt salinity [1]. Mackerel production in Lembata Regency until the end of 2016 was 209.27 tons [2]. The number of mackerel catches increased until 2016 by $53.23 \%$ [3]. Mackerel is nutritious because it contains protein, omega 3 , vitamin B12, vitamin D, vitamin B2, vitamin B6, phosphorus, iodine, and high selenium. Catch fish supplies such as mackerel cannot supply the increasing public demand due to natural factors such as rainfall and wind. One alternative to meet community demand for fish is aquaculture [4].

Intensive aquaculture causes the fish to experience stress, which lowers its immune system. It is a cause of increased susceptibility to disease $[5,6]$. Examples of infectious diseases are hemorrhagic and septicemia caused by the bacterial pathogen Aeromonas hydrophila [7] and Streptococcus agalactiae [8]. Symptoms of the disease are loss of appetite, red discoloration of the anus and base of the fins, eyes, gills, internal organs, and hemorrhagic muscles. Pathogenic bacterial infections are usually prevented by

\footnotetext{
* Correspondence address:

Helena Daten

Email : helenadaten061095@gmail.com

Address : Dept. Biology, University of Brawijaya, Veteran Malang, 65145
}

administering antibiotics, chemotherapy, and vaccines. Specifically for antibiotic therapy, if it is carried out intensively, it will result in the emergence of microbes that are resistant to these antibiotics $[9,10]$. One solution to solve this problem is the application of environmentally friendly and sustainable cultivation using probiotics [7].

Probiotics are beneficial microbes that can improve the health of their host and it can be used as a pathogenic biocontrol agent in aquaculture. Previous research obtained probiotics as biocontrol agents to be applied to aquaculture. Paenibacillus ehimensis NPUST1 isolated from tilapia ponds that have the ability to inhibit pathogens Aeromonas hydrophila and Streptococcus iniae [7], and Rummeliibacillus stabekisii can inhibit the growth of Streptococcus agalactiae [10]. Moreover, the consortium of Saccharomyces cerevisiae, Aspergillus oryzae, and Bacillus subtilis can also improve the immune system of tilapia and inhibit pathogens Aeromonas hydrophila and Streptococcus iniae [11]. Probiotics from mackerel intestines from the Indonesian sea have also been reported, namely Lactobacillus plantarum, Leuconostoc mesenteroides [14], and Bacillus megaterium (QM B1551 strain, NBRC15308 strain, IAM 13418 strain, and ATCC strain 14581) [13]. Probiotics from mackerel intestines, especially from Indonesia, are still less explored. Therefore, the research was aimed to isolate, characterize the $\mathrm{LAB}$ potential as probiotics, and analyze the ability of probiotics to produce hydrolase enzyme. 


\section{MATERIAL AND METHOD}

Sample Collection and Pathogenic Bacterial Strains Used

Mackerel was obtained from a fish auction place, Lewoleba Impres Market, Lembata Regency. Morphometry of 10 fishes included weight and length of mackerel. The mackerel was then brought under cold conditions to the Microbiology Laboratory, Faculty of Mathematics and Natural Sciences, Brawijaya University. Furthermore, the pathogen used was Aeromonas hydrophila obtained from the Fish Disease Laboratory, Faculty of Fisheries and Marine Sciences, Brawijaya University. Meanwhile, Streptococcus agalactiae was obtained from the Research Center for Freshwater Aquaculture Fisheries, Sempur, Bogor, West Java.

\section{Isolation and Characterization of LAB}

The length of the mackerel that has been used as a sample ranges from $18-19 \mathrm{~cm}$. The weight of the fish is 76.5-77.2 g. Mackerel intestine contents were removed using tweezers in sterile conditions. The fish intestine of $25 \mathrm{~g}$ was blended using a blender in $100 \mathrm{~mL}$ of $\mathrm{NaCl}$ $0.85 \%$. The obtained suspension was serially diluted from $10^{-1}-10^{-6}$ dilutions. Lactic acid bacteria were isolated by the spread plate method in MRS agar containing $1 \% \mathrm{CaCO}_{3}$ and incubated at $37^{\circ} \mathrm{C}$ for 48 hours. Lactic acid bacteria that grow are characterized by the formation of clear zones around the colony. Lactic acid bacteria were purified by the spread plate method. After that, Gram stain and catalase test were carried out to ensure that the isolates obtained were LAB [14].

\section{Screening of Antimicrobial Activity}

The antimicrobial activity test method used the well diffusion method as described by Speranza [15]. The number of cells of each lactic acid bacteria and pathogen is $10^{7} \mathrm{CFU} \cdot \mathrm{mL}^{-1}$. Lactic acid bacteria were cultured in MRS broth media, while Aeromonas hydrophila and Streptococcus agalactiae were cultured in Trypticase Soy Broth (TSB) media $[7,16]$. Pathogen isolates of $0.1 \mathrm{~mL}$ were spread on Trypticase Soy Agar (TSA) media. After that, $800 \mu \mathrm{L}$ of each lactic acid bacteria was put into a well with a diameter of $5 \mathrm{~mm}$, then incubated at $37^{\circ} \mathrm{C}$ for 48 hours. Clear zone diameters were measured and the inhibition index was calculated with formula 1 [17].

Inhibitory index $=\frac{\text { clearzone diameter }- \text { well diameter }}{\text { well diameter }} \ldots . . . . . . . . .1$...
In-vitro Tests for Probiotic Properties: Tolerance to low pH, Bile salt, and Salinity

The $\mathrm{pH}$ variations used were $\mathrm{pH} 1,3$, and 5 , while the concentration of bile salts used were $2.5 \%, 5 \%$, and $7.5 \%$ [14]. The salinity variation used were $0.5 \%, 3 \%$, and $6.5 \%$ [18]. Lactic acid bacteria that have antimicrobial activity and were used for further tests are KBP 3.3, KBP 4.3, KBP 4.2.1, and KBP 1.1.1. Lactic acid bacteria were each added as much as $10 \%$ with a cell density of $10^{7}$ CFU. $\mathrm{mL}^{-1}$ into the MRS broth as measured by $\mathrm{pH}$, bile salts, and salinity. Then, incubated at $37^{\circ} \mathrm{C}$ for 24 hours and sampling at 0,4 , and 24 hours to determine the number of cells using a hemocytometer [19]. The survival rate of lactic acid bacteria was calculated using formula 2 [20]. The N1 is the final cell amount and NO is the initial cell amount.

$$
\text { Survival rate } \left.(\%)=\frac{\log N 1}{\log N O} \times 100 \ldots \ldots \ldots \ldots . . . .2\right)
$$

\section{Auto-Aggregation Property}

Lactic acid bacteria culture with $10^{7} \mathrm{CFU} \cdot \mathrm{mL}^{-1}$ cells was centrifuged at $6000 \mathrm{rpm}$, at room temperature for 10 minutes. The pellet was suspended in a saline buffer $(0.85 \% \mathrm{NaCl})$ to 15 $\mathrm{mL}$. The suspension was measured optical density (OD) at a wavelength of $600 \mathrm{~nm}$. After that, the suspension was left for 60 minutes at room temperature, then the suspension was recentrifuged at $3000 \mathrm{rpm}$ for 2 minutes and the supernatant was measured again at the same wavelength. The percentage of auto-aggregation was calculated using formula 3 [21].

$$
\text { \% Auto-aggregation } \left.=\frac{(\mathrm{ODO}-\mathrm{OD} 60)}{\mathrm{ODO}} \times 100 \ldots \ldots . . .3\right)
$$

\section{Enzymatic Activity}

Hydrolase enzyme activities tested were protease, amylase, lipase, and cellulase enzymes. This test was used the paper disc diffusion method. Protease enzyme activity was tested using skim milk media and amylase test using agar strach [21]. Lipase test was used lipolytic agar [22] and cellulase test was used carboxymethyl cellulose (CMC) agar [23]. After that, incubation at $37{ }^{\circ} \mathrm{C}$ for 48 hours and clear zone was formed and also the hydrolysis index was calculated using formula 4 [22].

$$
\text { Indeks hidrolisis= } \frac{\text { Diameter of clearzone }}{\text { Diameter of disc }}
$$




\section{RESULT AND DISCUSSION}

The number of lactic acid bacteria obtained was eleven isolates. All of the LAB isolates were negative catalase and Gram-positive. The LAB cells are basil (KBP 1.1.1, KBP 3.3, KBP 2.1, and $K B P$ 1.1.2.1) with cell sizes of $2-3 \mu \mathrm{m}$, and cocci (KBP 3.1, KBP 3.2, KBP 4.3, KBP 6.2, KBP 4.2, KBP 2.3, and KBP 4.2.1) sizes of $\pm 1 \mu \mathrm{m}$. The number of isolated lactic acid bacterial cells was $7 \times 10^{6}$ CFU. $\mathrm{g}^{-1}$. The number of LAB cells in the intestines of marine fish is usually constant during the capture and storage period of $10^{6}-10^{7} \mathrm{CFU} \cdot \mathrm{g}^{-1}$. The fish intestine is a potential source of probiotics because $L A B$ cell viability remains stable, compared to probiotics isolated from gills and fish skins. The amount of LAB that commonly lives in the intestines of mackerel is $2 \times 10^{6}$ CFU.g ${ }^{-1}$ [24]. The LABs are not dominant in the normal intestinal microbiota of fish, at variance with homeotherms, but some strains can colonize the intestine [25].

The LAB is found and symbiotic throughout the gastrointestinal tract, including the stomach and the intestines [26]. The population level of lactic acid bacteria associated with the intestine is affected by nutritional and environmental factors like chromic oxide, stress, and salinity [27]. Although some lactic acid bacteria strains can colonize the intestine of the host, living acid bacteria from food or feed preparations, are in most cases, lost from the intestine within a few days after the intake has stopped [24]. The fish intestine is prebiotic for supplementation of materials that can support the growth of LAB in the intestinal tract of hosts, while beneficial bacteria, a bacterial group of lactic acid bacteria (LAB), has elicited most interest due to their ability to release various beneficial compounds such as free fatty acids (FFA), digestive enzymes, and antimicrobial compounds [28].

\section{Antimicrobial activity}

Probiotics can inhibit pathogens by providing nutrients and enzymes to increase host growth, enhance the immune response by stimulating the immune system, and not causing environmental pollution [8]. Probiotics have inhibitory activity if the inhibitory index values range of 2.2-4.4 (moderate-very strong category) [29]. Therefore, the results show that KBP 1.1.1, KBP 3.3, KBP 4.3, and KBP 4.2.1 are the isolates that have inhibitory activity against Aeromonas hydrophila. The isolate with the highest inhibitory index value was the KBP 3.3 isolate of 7.16 ( $p<0.05$ ). Other isolates that have high inhibitory ability are $\mathrm{KBP}$ 4.2.1, KBP 4.3, and KBP 1.1.1, with an inhibitory index value of 4.5, 4.1, and 2.3, respectively (Fig. 1).

Inhibitory activity by $L A B$ against pathogens is carried out using the metabolites it produces. Probiotics Bacillus licheniformis KADR5 and Bacillus pumilus KADR6 are able to inhibit Aeromonas hydrophila ATCC 49140 (inhibitory index > 1.6) due to the activity of lysozyme enzymes by damaging the cell wall of pathogenic bacteria [30]. In addition, several probiotics have inhibitory activity against Aeromonas hydrophila Ah01, such as Lactococcus lactis Q-8, L. lactis Q-9, and L. lactis Z-2 [29]. This inhibitory activity is due to lactic acid compounds, which suppress lipopolysaccharide (LPS) production and damage the Gram-negative bacterial membrane [31].

Another pathogen that causes disease in fish is Streptococcus agalactiae. Inhibitory activity occurs if probiotics have inhibitory index values in the moderate-strong category (1 to 2.6) [9]. The results showed that KBP 1.1.1 and KBP 4.2.1 inhibit pathogens with inhibitory index values of 3.24 and 2.89, respectively (Fig. 2).

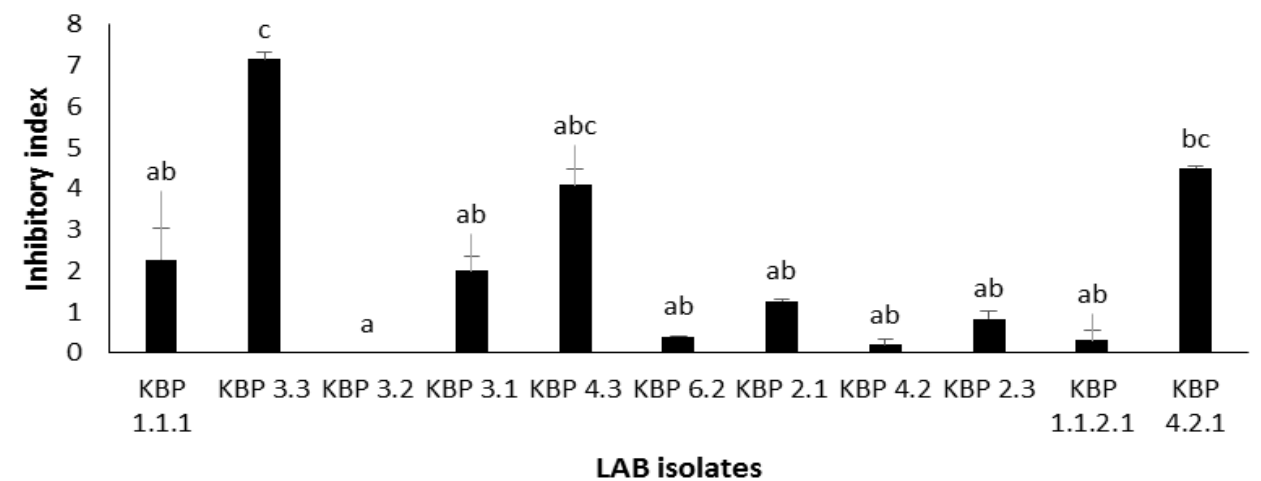

Figure 1. Antimicrobial activity of lactic acid bacteria against Aeromonas hydrophila 


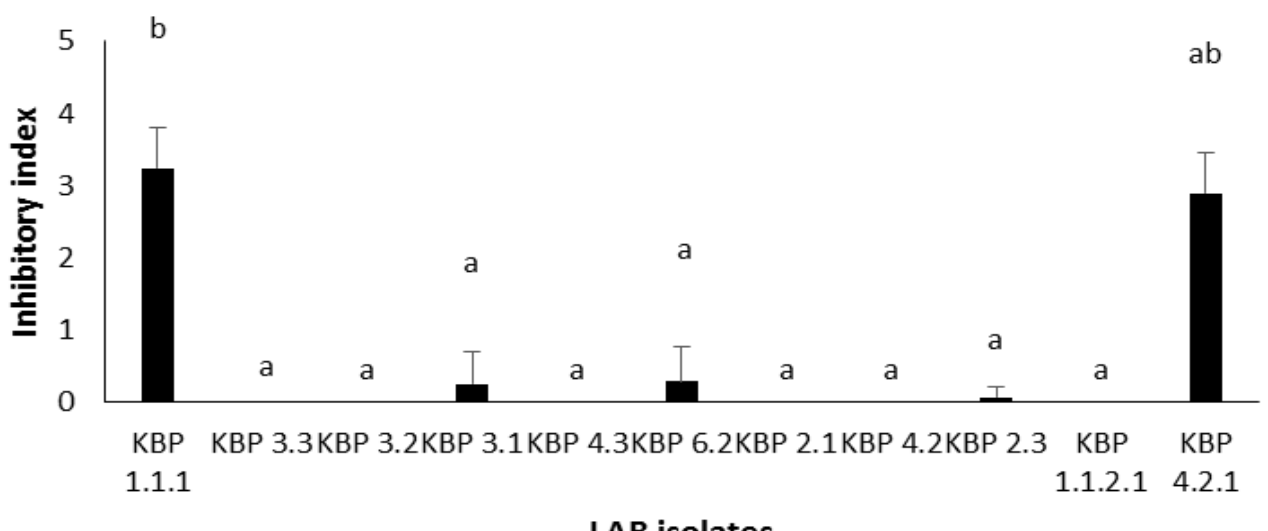

Figure 2. Antimicrobial activity of lactic acid bacteria against Streptococcus agalactiae

Bacteriocin type nisin A and organic acids produced by Lactococcus lactis subsp. lactis CRL 1655 is inhibiting the pathogen Streptococcus agalactiae [32]. Probiotics such as Bacillus cereus NY5 and Bacillus subtilis also have the ability to inhibit the pathogen Streptococcus agalactiae due to increased lyzc gene expression to produce the enzyme lysozyme [8]. Previous studies showed that the c-type lysozymes were effective in lysing both Gram-negative and Gram-positive strains. The host could recognize the bacterial challenges, generate acute stress, and enhance body immunity by secreting specific proteins such as lysozymes [33]. Moreover, some lactic acid bacteria produce bacteriocin which inhibits Streptococcus agalactiae, with an inhibitory index of 0.6-1.8, namely Enterococcus faecium BNM58 and Weissella cibaria BNM69 [34]. In this study, KBP 4.2.1 isolate is a potential isolate that has the ability to inhibit pathogens Aeromonas hydrophila and Streptococcus agalactiae.

\section{Low pH Tolerance}

One of the probiotic criteria is tolerance of the fish's gastrointestinal conditions [35]. The stomach $\mathrm{pH}$ value of tilapia ranges about 1.5 $5.8[14,36,37]$. The intestinal $\mathrm{pH}$ value of tilapia ranges about $6.9-7.0[14,37]$. Therefore, based on the results, tolerant lactic acid bacteria isolate of gastric $\mathrm{pH}(1,3$, and 5) are KBP 3.3 and KBP 1.1.1. The survival rate of the two isolates at $\mathrm{pH} 1$ was significantly different from the other two isolates for 24 hours. The survival rate of KBP 3.3 at $\mathrm{pH} 1$ decreased insignificantly after incubation at $4-24$ hours, from $94.7 \%$ to $93 \%$, while the survival rate of KBP 1.1.1 increased from $95.98 \%$ to $98.3 \%$ (Fig. 3).

The isolate of KBP 3.3 had the highest survival rate at $4-24$ hours, $100.86 \%$ to $98.89 \%$. The isolate of KBP 4.2.1 had a lower survival rate than the other three isolates at $4-24$ hours, $35 \%$ to $34 \%$. The survival rate at $\mathrm{pH} 5$ did not show a significant difference (Fig. 3). Previous studies have shown that Lactococcus lactis CLFP 101, Lactobacillus plantarum CLFP 238, and Lactobacillus fermentum CLFP 242 were tolerant to $\mathrm{pH} 3$ and 5 , while at $\mathrm{pH} 1$, no isolates survived [38]. Moreover, the LAB that tolerate at $\mathrm{pH} 1$ are Lactococcus lactis (strains $8 \mathrm{HT}, 9 \mathrm{HT}, 11 \mathrm{HT}$ and $33 \mathrm{HT}$ ) and Enterococcus faecalis $14 \mathrm{HT}$ [39]. Other bacteria are Leuconostoc mesenteroides [40] and Pediococcus pentosaceus tolerance to $\mathrm{pH} 3$ and 5 with a survival rate of $75 \%$ [41]. Therefore, KBP 3.3 and KBP 1.1.1 have a higher tolerance at $\mathrm{pH}$ 1,3 , and 5 compared to previous studies.

\section{Bile Tolerance}

Tilapia and freshwater fish generally have concentrations of bile salts ranging from 1-10\% $[14,36]$. Therefore, the results showed that KBP 3.3 and KBP 1.1.1 isolates were tolerant of the concentration of bile salt $2.5-7.5 \%$. The survival rate of the two isolates at 4-24 was above $97 \%$. However, KBP 3.3 isolate was one of the isolates that showed an increase in cell number during oxgal exposure of $2.5 \%$ (Fig. 4).

Along with the increase in bile salts, the survival rate of KBP 3.3 and KBP 1.1.1 did not decrease. The results of previous studies indicate that the more increased the concentration of bile salts, the value of survival rate decreases. With variations in bile salt concentrations of 2.5, 5.0, 7.5 , and $10 \%$ it was reported that the survival rate of Lactococcus lactis CLFP 101, Lactobacillus plantarum CLFP 238, and Lactobacillus fermentum CLFP 242 was 100\% [38]. Moreover, Lactococcus lactis (strains $8 \mathrm{HT}, 9 \mathrm{HT}, 11 \mathrm{HT}$ and $33 \mathrm{HT}$ ) and Enterococcus faecalis $14 \mathrm{HT}$ also tolerance at $10 \%$ bile salt concentrations [39]. 


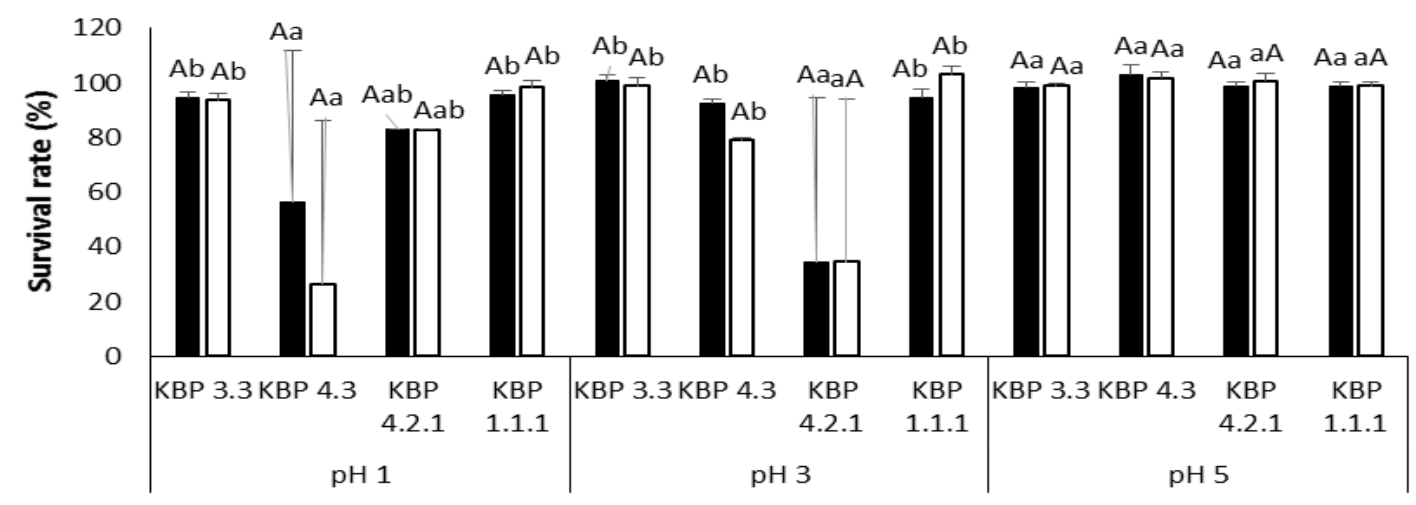

LAB isolates and pH

Q 4 hours $\square 24$ hours

Figure 3. Lactic acid bacteria tolerance at $\mathrm{pH} 1,3$, and 5

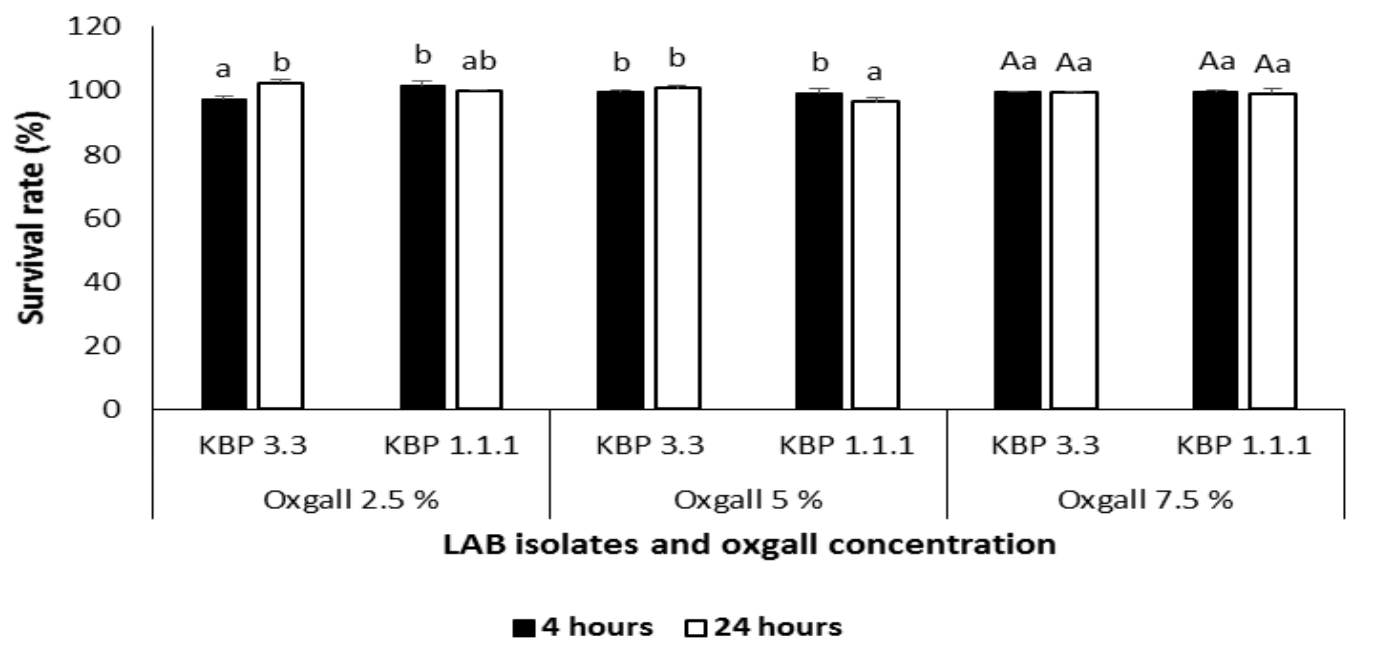

Figure 4. Lactic acid bacteria tolerance to bile salt concentration

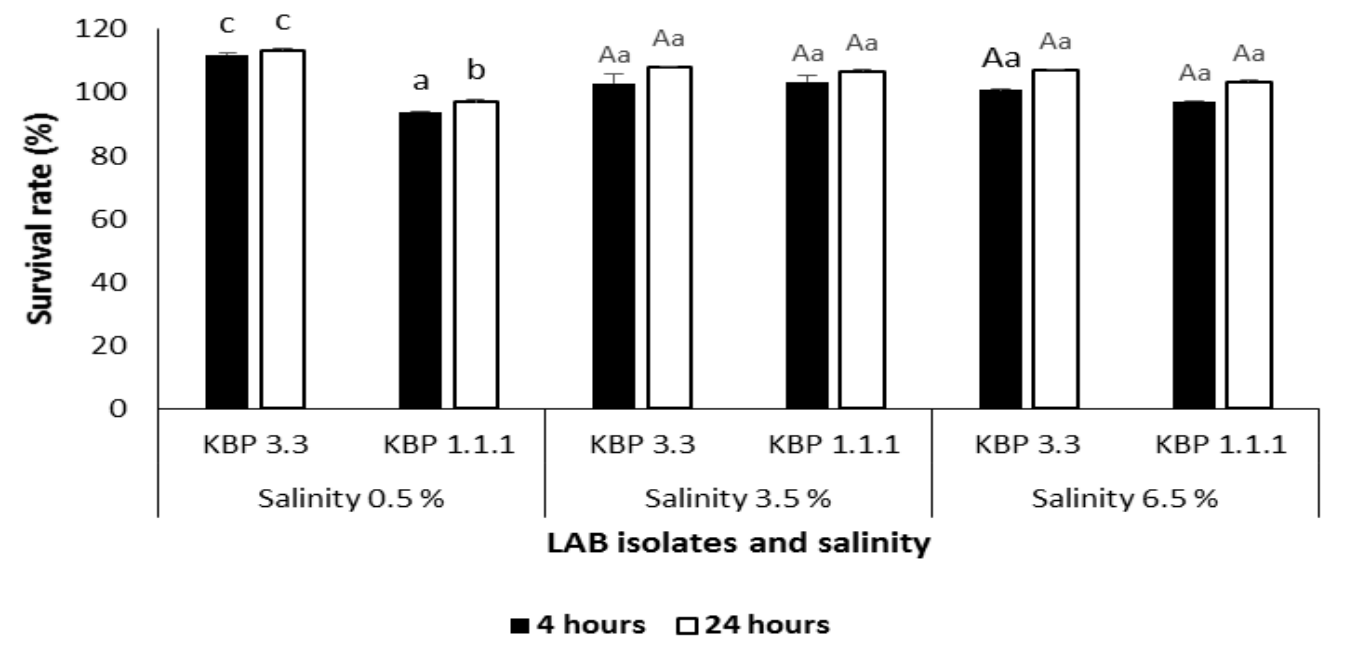

Figure 5. Tolerance of lactic acid bacteria to salinity 


\section{Salinity Tolerance}

Lactic acid bacteria can be found in some seawater fish that live in tropical seas. The population of lactic acid bacteria in the aquatic environment is influenced by the temperature and salinity of freshwater [42]. Seawater salinity concentrations in Lembata regency ranged from 33.86-34.85 PSU, while water temperatures ranged from $3 \cdot 5-30.01^{\circ} \mathrm{C}[43,44,45]$. Moreover, freshwater salinity, in general, is 0.5-6.5\% [20]. Therefore, lactic acid bacteria with probiotic potency must tolerance the host environment.

The results showed that KBP 3.3 and KBP 1.1.1 isolates were tolerant of freshwater salinity. The survival rate of KBP 3.3 and KBP 1.1.1 are above $100 \%$. It shows that the $L A B$ can maintain the number at 24 hours in the range of salinity $0.5-6.5 \%$ (Fig. 5). The salinity affects the ability of probiotics. It is supported by previous research that Lactobacillus is more commonly found in freshwater fish [46], while the Streptococcus species is more found in marine fish [47]. If Lactobacillus species are applied to marine fish, the numbers will decrease, while the number of Streptococcus species does not change [42]. Lactic acid bacteria have the ability to tolerate environmental conditions because of their ability to produce lizosim enzymes. Lizosim plays a role in inhibiting pathogenic microbes and surviving in environmental stressful conditions such as $\mathrm{pH}$, low salinity, and temperature [48-51].

\section{Auto-aggregation Assays}

One of the probiotic criteria is to have the ability to colonize in the host intestine [52]. The ability of autoaggregation of probiotics is excellent if the value of autoaggregation is above $30-60 \%$ [53]. The results showed that KBP 3.3 and KBP 1.1.1 have the potency to colonize in the host intestine. It is supported by the autoaggregation values of the two isolates above $50 \%$. However, the autoaggregation value of KBP 3.3 was higher $(92.18 \%)$ compared to KBP 1.1.1 (87.84 \%).

The autoaggregation property depends on bacterial strains, so it varies greatly among the same bacterial species $[54,55]$. The good of autoaggregation property is not only seen from the results of the in vitro test but is supported by the in vivo test because many factors influence these characteristics, such as the host, defense mechanisms, native microbes in the intestine, and peristalsis [54]. Some LAB reported to have the ability to colonize are Enterococcus faecium strain CGMCC1.2136 (9.05\%) [56], Lactococcus cremoris SMF110 (40.3\%), Lactococcus cremoris SMM69 (20.1\%), Lactobacillus curvatus BCS35 (17.9\%), Enterococcus faecium SMF110 (40.3\%), Lactococcus cremoris SMM69 (20.1\%) [57], Lactobacillus plantarum (11.5\%), Lactobacillus fermentum (14.2\%), and Lactococcus lactis (17.2\%) [38].

\section{Enzymatice Activity}

Lactic acid bacteria with probiotics potency work optimally if producing hydrolase enzymes [58]. Carnivorous and omnivorous freshwater fish need probiotics that have the activity of the enzyme hydrolase (protease, lipase, amylase, and cellulase) to help the digestive process of fish [59]. The results indicate that KBP 3.3 and KBP 1.1.1 isolates have the activity of the enzyme hydrolase, except for the amylase enzyme. The isolate of KBP 3.3 had the highest lipase enzyme activity (hydrolysis index of 2.96), while KBP 1.1.1 had the highest protease enzyme activity of 3.28 (Fig. 6).

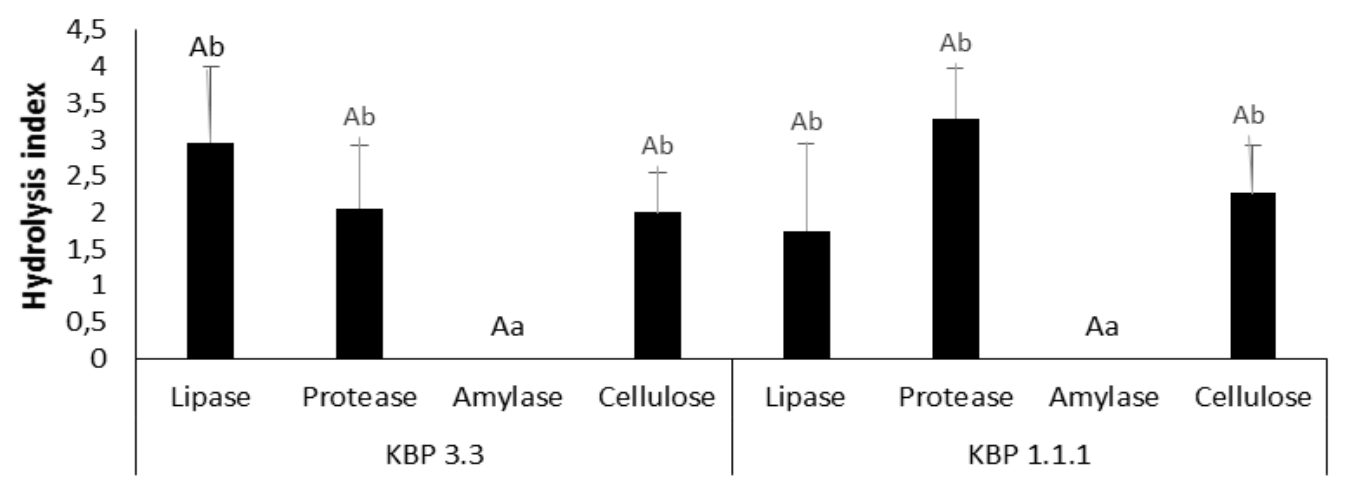

LAB isolates and hydrolaze enzyme

Figure 6. Hydrolase enzyme activity produced by lactic acid bacteria 
Lactic acid bacteria generally have the activity of the hydrolase enzyme. It is supported by previous studies, namely Enterococcus faecium [60], Lactobacillus curvatus and Leuconostoc mesenteroides produce the enzyme protase, lipase, and amylase [61], Lactococcus lactis and Enterococcus faecalis produce enzymes protease and amylase [39], while Carnobacterium sp. produced cellulase enzymes [62]. This study together with others, confirmed that enzyme production varied according to bacterial species and food habits $[63,64]$.

\section{CONCLUSION}

Lactic acid bacteria were successfully isolated from the intestines of mackerel as much as eleven isolates. The isolates of KBP 3.3 and KBP 4.3 are isolates that have the ability to inhibit Aeromonas hydrophila, KBP 1.1.1 have the ability to inhibit Streptococcus agalactiae, while KBP 4.2.1 have the ability to inhibit the two pathogens. The isolates of KBP 3.3 and KBP 1.1.1 tolerant to low $\mathrm{pH}$, high bile salt concentrations, and low water salinity. Both of these isolates also have the ability to produce the enzymes protease, lipase, and cellulase.

\section{REFERENCES}

[1] Kongseng, S., R. Phoonsawat, A. Swatdipong. 2020. Individual assignment and mixed-stock analysis of short mackerel (Rastrelliger brachysoma) in the Inner and Eastern Gulf of Thailand. Fish. Res. 221. 105-372.

[2] Statistic Center of East Nusa Tenggara. 2018. Mackerel production based on Regency/City in East Nusa Tenggara Province 2015-2016. Available at: https://ntt.bps.go.id/dynamictable/2018/0 2/09/611/produksi-ikan-kembungmenurut-kabupaten-kota-di-provinsi-nusatenggara-timur-2015-2016.html.

[3] Ministry of Marine and Fisheries. 2018. Business potential and investment opportunities for marine and fisheries in the Province of East Nusa Tenggara. Directorate General of Strengthening Competitiveness of Marine and Fisheries Products. 1-63.

[4] Nurdin, S., M. A. Mustapha, T. Lihan, M. Zainuddin. 2017. Applicability of remote sensing oceanographic data in the detection of potential fishing grounds of Rastrelliger kanagurta in the archipelagic waters of Spermonde, Indonesia. Fish. Res. 196. 1-12.

[5] Cerezuela, R., F.A. Guardiola, P. Gonzalez, J. Meseguer, M.A. Esteban. 2012. Effects of dietary Bacillus subtilis, Tetraselmis chuii, and Phaeodactylum tricornutum, singularly or in combination, on the immune response and disease resistance of sea bream (Sparus aurata L.). Fish Shellfish Immunol. 9(33). 342.

[6] Aly, S. M., Y.A. Ahmed, A.A.G. Aziz, M.F. Mohamed. 2008. Studies on Bacillus subtilis and Lactobacillus acidophilus, as potential probiotics, on the immune response and resistance of Tilapia nilotica (Oreochromis niloticus) to challenge infections. Fish Shellfish Immunol. 25(1-2). 128-136.

[7] Chen, S.W., C.H. Liu, S.Y. Hu. 2019. Dietary administration of probiotic Paenibacillus ehimensis NPUST1 with bacteriocin-like activity improves growth performance and immunity against Aeromonas hydrophila and Streptococcus iniae in Nile tilapia (Oreochromis niloticus). Fish Shellfish Immunol. 84. 695-703.

[8] Xia, Y., M. Wang, F. Gao, M. Lu, G. Chen. 2020. Effects of dietary probiotic supplementation on the growth, gut health and disease resistance of juvenile Nile tilapia (Oreochromis niloticus). Animal Nutrition. 6(1). 69-79.

[9] Gobi, N., B. Vaseeharan, J.C. Chen, R. Rekha, S. Vijayakumar, M. Anjugam. 2018. Dietary supplementation of probiotic Bacillus licheniformis Dahb1 improves growth performance, mucus and serum immune parameters, antioxidant enzyme activity as well as resistance against Aeromonas hydrophila in tilapia Oreochromis mossambicus. Fish Shellfish Immunol. 74. 501-508.

[10] Tan, H.Y., S. Chen, S. Hu. 2019. Improvements in the growth performance, immunity, disease resistance, and gut microbiota by the probiotic Rummeliibacillus stabekisii in Nile tilapia (Oreochromis niloticus). Fish Shellfish Immunol. 92. 265-275.

[11] Iwashita, M.K.P., I.B. Nakandakare, J.S. Terhune. 2015. Dietary supplementation with Bacillus subtilis, Saccharomyces cerevisiae and Aspergillus oryzae enhance immunity and disease resistance against Aeromonas hydrophila and Streptococcus 
iniae infection in juvenile tilapia Oreochromis niloticus. Fish Shellfish Immunol. 43(1). 60-66.

[12] Kanno, T., T. Kuda, C. An, H. Takahashi, B. Kimura. 2012. Radical scavenging capacities of saba-narezushi, Japanese fermented chub mackerel, and its lactic acid bacteria. LWT - Food Sci. Technol. 47(1). 25-30.

[13] Ismail, Y.S., Febriani, C. Yulvizar, R. Ramadhani. 2019. Identification of the bacterium isolate from Mackerel Fish (Rastrelliger sp.) using 16S rRNA Gene. IOP Conference Series: Earth and Environmental Science. 293. 12-43.

[14] Kavitha, M, M. Raja, P. Perumal. 2018. Evaluation of probiotic potential of Bacillus spp. isolated from the digestive tract of freshwater fish Labeo calbasu. Aquac. Rep. 11. 59-69.

[15] Speranza, B., A. Racioppo, L. Beneduce. 2017. Autochthonous lactic acid bacteria with probiotic aptitudes as starter cultures for fish-based products. Food Microbiol. 65. 244-253.

[16] Zhang, L., C. Wang, H. Liu, P. Fu. 2019. The important role of phagocytosis and interleukins for nile tilapia (Oreochromis niloticus) to defense infection of Aeromonas hydrophila based on transcriptome analysis. Fish Shellfish Immunol. 92. 54-63.

[17] Wahyuni, D.S., M.B. Sudarwanti, P. Lisdiyanti. 2014. Screening of antibacterial activities of actinomycetes isolates from Indonesia. Glob. Vet. 13(2). 266-272.

[18] Raj, N.S., T.R. Swaminathan, A. Dharmaratnam, S.A. Raja, D. Ramraj, K.K. Lal. 2019. Aeromonas veronii caused bilateral exophthalmia and mass mortality in cultured Nile tilapia, Oreochromis niloticus (L.) in India. Aquaculture. 512. 734278.

[19] Asaduzzaman, M., M. Ohya, H. Kumura. 2020. Searching for high ZnPP-forming edible bacteria to improve the color of fermented meat products without nitrite/nitrate. Meat Sci. 165. 108-109.

[20] Rajoka, M.Sh.R, H.F. Hayat, S. Sarwar, H.M. Mehwish, F. Ahmad, N. Hussain, et al. 2018. Isolation and evaluation of probiotic potential of lactic acid bacteria isolated from poultry intestine. Microbiology. 87(1). 116-126.
[21] Padmavathi, T., R. Bhargavi, P.R. Priyanka, N.R. Niranjan, P.V. Pavitra. 2018. Screening of potential probiotic lactic acid bacteria and production of amylase and its partial purification. J. Gen. Eng. Biotechnol. 16(5). 357-362.

[22] Niken, C.B., Suharjono. 2015. Uji kualitatif dan kuantitatif isolat bakteri lipolitik dari limbah cair pabrik pengolahan ikan Kecamatan Muncar, Banyuwangi. Jurnal Tropika. 3(3). 151-155.

[23] Habbale, D., R. Bhargavi, T.V. Ramachandra. 2019. Saccharification of macroalgal polysaccharides through prioritized cellulase producing bacteria. Heliyon. 5. 1372.

[24] Svanevik, C.M., B.T. Lunestad. 2011. Characterisation of the microbiota of Atlantic mackerel (Scomber scombrus). Int. J. Food Microbiol. 151. 164-170.

[25] Gänzle, M.G. Lactic metabolism revisited: metabolism of lactic acid bacteria in food fermentations and food spoilage. Curr. Opin. Food Sci. 2. 106-117.

[26] Parada, J.L., C.R. Caron, A.B.P. Medeiros, C.R. Soccol. 2007. Bacteriocins from Lactic Acid Bacteria: Purification, Properties and use as Biopreservatives. Braz. Arch. Biol. Technol. 50. 521-542.

[27] Françoise, L. 2010. Occurrence and role of lactic acid bacteria in seafood products. Food Microbiol. 27. 698-709.

[28] Bairagi A., K.S. Ghosh, S.K. Sen, A.K. Ray. 2002. Enzyme producing bacterial flora isolated from fish digestive tracts. Aquac. Int. 10(2). 109-121.

[29] Feng, J., X. Chang, Y. Zhang, X. Yan, J. Zhang, G. Nie. 2019. Effects of Lactococcus lactis from Cyprinus carpio L. as probiotics on growth performance, innate immune response and disease resistance against Aeromonas hydrophila. Fish Shellfish Immunol. 93. 73-81.

[30] Ramesh, D., A. Vinothkanna, A.K. Rai, V.S. Vignesh. Isolation of potential probiotic Bacillus spp. and assessment of their subcellular components to induce immune responses in Labeo rohita against Aeromonas hydrophila. Fish Shellfish Immunol. 45. 268-276.

[31] Alakomi, H.L., E. Skyttä, M. Saarela, T. Mattila-Sandholm, K. Latva-Kala, I.M. Helander. 2000. Lactic acid permeabilizes gram-negative bacteria by disrupting the 
outer membrane, Application. Environ. Microbiol. 66. 2000-2001.

[32] Espeche, M.C., M.C. Otero, F. Sesma, M. Nader, M.E. Fatima. 2009. Screening of surface properties and antagonistic substances production by lactic acid bacteria isolated from the mammary gland of healthy and mastitic cows. Vet. Microbiol. 135(3-4). 346-357.

[33] Gao, F.Y., L. Qu, S.G. Yu, X. Ye, Y.Y. Tian, L.L. Zhang. 2012. Identification and expression analysis of three c-type lysozymes in Oreochromis aureus. Fish Shellfish Immunol. 32 (5). 779-488.

[34] Muñoz-Atienza, E., B. Gómez-Sala, C. Araújo, C. Herranz, L.M. Cintas. 2013. Antimicrobial activity, antibiotic susceptibility and virulence factors of Lactic Acid Bacteria of aquatic origin intended for use as probiotics in aquaculture. $B M C$ Microbiol. 13(1). 1-22.

[35] Guo, X., D.D. Chen, K.S. Peng, Z.W. Cui, X.J. Zhang, S. Li. 2016. Identification and characterization of Bacillus subtilis, from grass carp (Ctenopharynodon idellus) for use as probiotic additives in aquatic feed. Fish Shellfish Immunol. 52. 74-84.

[36] Pinpimai, K., C. Rodkhum, N. Chansue, T. Katagiri., M. Maita, N. Pirarat. 2015. The study on the candidate probiotic properties of encapsulated yeast, Saccharomyces cerevisiae JCM 7255, in Nile Tilapia (Oreochromis niloticus). Res. Vet. Sci. 102. 103-111.

[37] Zidni, I., E. Afrianto, I. Mahdiana, H. Herawati. 2017. Laju pengosongan lambung ikan mas (Cyprinus carpio) dan ikan nila (Oreochoromis niloticus). Jurnal Perikanan dan Kelautan. 9(2). 147-151.

[38] Balcázar, J.L., D. Vendrell, I. de Blas, I. RuizZarzuela, J.L. Muzquiz, O. Girones. 2008. Characterization of probiotic properties of lactic acid bacteria isolated from intestinal microbiota of fish. Aquaculture. 278. 188191.

[39] Reda, R.M., K.M. Selim., H.M. El-Sayed, M.A. El-Hady. 2018. In vitro selection and identification of potential probiotics isolated from the gastrointestinal tract of Nile tilapia, Oreochromis niloticus. Probiotics Antimicro. 10. 692-703.

[40] Allameh, S.K., H. Daud, F.M. Yusoff, C.R. Saad, A. Ideris. 2012. Isolation, identification and characterization of Leuconostoc mesenteroides as a new probiotic from intestine of snakehead fish (Channa striatus). Afr. J. Biotechnol. 11(16). 3810-3816.

[41] Jaafar, R.S., F.N. Al-Knany, B.A. Mahdi, A.M. R. Al-Taee. 2019. Study the Probiotic Properties of Pediococcus pentosaceus Isolated from Fish Ponds in Basra City, South of Iraq. J. Pure Appl. Microbiol. 13(4). 2343-2351.

[42] Al Bulushi, I.M., S.E. Poole, R. Barlow, H.C. Deeth, G.A. Dykes. 2010. Speciation of Gram-positive bacteria in fresh and ambient-stored sub-tropical marine fish. Int. J. Food Microbiol. 138(1-2). 32-38.

[43] Stanis, S. 2005. Pengelolaan sumberdaya pesisir dan laut melalui pemberdayaan kearifan lokal di kabupaten Lembata propinsi Nusa Tenggara Timur. Master Thesis. Graduate School, Diponegoro University. Semarang.

[44] Slamet, A. 2019. Analisis massa air di perairan utara pulau Lembata, Nusa Tenggara Timur. Master Thesis. Department of Marine Science and Technology, Faculty of Fisheries and Marine Sciences, Bogor Agricultural University.

[45] Tubalawony, S., E. Kusmanto, Muhadjirin. 2012. Suhu dan salinitas permukaan merupakan indikator upwelling sebagai respon terhadap angin muson tenggara di perairan bagian utara laut Sawu. IImu Kelautan. 17(4). 226-239.

[46] Bucio, A., R. Hartemink, J. W. Schrama, J. Verreth, F.M. Rombouts. 2006. Presence of lactobacilli in the intestinal content of freshwater fish from a river and from a farm with a recirculation system. Food Microbiol. 23(5). 476-482.

[47] Baeck, G.W., J.H. Kim, D.K. Gomez, S.C. Park. 2006. Isolation and characterization of Streptococcus sp. from diseased flounder (Paralichthys olivaceus) in Jeju Island. J. Vet. Sci. 7(1). 53-58.

[48] Dong, H.B., Y.Q. Su, Y. Mao. 2014. Dietary supplementation with Bacillus can improve the growth and survival of the kuruma shrimp Marsupenaeus japonicus in high temperature environments. Aquac. Int. 22. 607-617.

[49] Liu, K.F., C.H. Chiu, Y.L. Shiu, Y.W. Cheng, C.H. Liu. 2010. Effects of the probiotic, Bacillus subtilis E20, on the survival, development, stress tolerance, and immune status of white shrimp, Litopenaeus 
vannamei larvae. Fish Shellfish Immunol. 28. 837-844.

[50] Lin, Y.C., C.M. Tayag, C.L. Huang, W.C. Tsui, J.C. Chen. 2010. White shrimp Litopenaeus vannamei that had received the hot-water extract of Spirulina platensis showed earlier recovery in immunity and up-regulation of gene expressions after $\mathrm{pH}$ stress. Fish Shellfish Immunol. 29. 1092-1098.

[51] Soonthornchai, W., W. Rungrassamee, N. Karoonuthaisiri, P. Jiravanichpaisal. 2010. Expression of immune-related genes in the digestive organ of shrimp, Penaeus monodon, after an oral infection by Vibrio harveyi. Dev. Comp. Immunol. 34. 19-28.

[52] Kos, B., J. Suskovic, S. Vukovic, M. Simpraga, J. Frece, S.M. Matosic. 2003. Adhesion and aggregation ability of probiotic strain Lactobacillus acidophilus M92. J. Appl. Microbiol. 94. 981-987.

[53] Fernandez-Pacheco, P., M. Arévalo-Villena, A. Bevilacqua, M.R. Corbo, A. Briones Pérez. 2018. Probiotic characteristics in Saccharomyces cerevisiae strains: Properties for application in food industries. LWT Food Sci. Technol. 97. 332-340.

[54] Caggia, C., M. De Angelis, I. Pitino, A. Pino, C. Randazzo. 2015. Probiotic features of Lactobacillus strains isolated from Ragusano and Pecorino Siciliano cheeses. Food Microbiol. 50. 109-117.

[55] Das, P., S. Khowala, S. Biswas. 2016. In vitro probiotic characterization of Lactobacillus casei isolated from marine samples. LWT Food Sci. Technol. 73. 383-390.

[56] Tarkhani, R., A. Imani, S.H. Hoseinifar, O. Ashayerizadeh, K.S. Moghanlou, R. Manaffar, H.V. Doan, M. Reverter. 2019. Comparative study of host-associated and commercial probiotic effects on serum and mucosal immune parameters, intestinal microbiota, digestive enzymes activity and growth performance of roach (Rutilus rutilus caspicus) fingerlings. Fish Shellfish Immunol. 19. 1-35.

[57] Munoz-Atienza, E., C. Araújo, S. Magadan, P.E. Hernandez. 2014. In vitro and in vivo evaluation of lactic acid bacteria of aquatic origin as probiotics for turbot (Scophthalmus maximus L.) farming. Fish Shellfish Immunol. 41. 570-580.

[58] Pundir R.K., S. Rana, N. Kashyap, A. Kaur. 2013. Probiotic potential of lactic acid bacteria isolated from food samples: an in vitro study. J. Appl. Pharmaceut. Sci. 3(3). 85-93.

[59] Agung, L.A., Widanarni, M. Yuhana. 2015. Application of micro-encapsulated probiotic Bacillus NP5 and prebiotic mannan oligosaccharide (MOS) to prevent streptococcosis on tilapia Oreochromis niloticus. Res. J. Microbiol. 10(12). 571-581.

[60] Shin, H.J., H.J. Choi, D.W. Kim, C.S. Ahn, Y.G. Lee, Y.K. Jeong. 2012. Probiotic potential of Pediococcus pentosaceus BCNU 9070. J. Life Sci. 22. 1194-1200.

[61] Askarian, F., A. Kousha, W. Salma, E. Ring $\varnothing$. 2011. The effect of lactic acid bacteria administration on growth, digestive enzyme activity and gut microbiota in Persian sturgeon (Acipenser persicus) and beluga (Huso huso) fry. Aquac. Nutr. 17(5). 488497.

[62] Askarian, F., Z. Zhou, R.E. Olsen, S. Sperstad, E. Ring $\varnothing$. 2012. Culturable autochthonous gut bacteria in Atlantic salmon (Salmo salar L.) fed diets with or without chitin. Aquaculture. 326. 1-8.

[63] Saha, S., R.N. Roy, S.K. Sen, A.K. Ray. 2006. Characterization of cellulose producing bacteria from the digestive tract of tilapia, Oreochromis mossambica (Peters) and grass carp, Ctenopharyngodon idella (Valenciennes). Aquac. Res. 37(4). 380-388.

[64] Ambas, I., N. Buller, R. Fotedar. 2015. Isolation and screening of probiotic candidates from marron, Cherax cainii, gastrointestinal tract (GIT) and commercial probiotic products for the use in marron culture. J. Fish Dis. 38(5). 467-476. 